International Journal of Current Advanced Research

ISSN: O: 2319-6475, ISSN: P: 2319 - 6505, Impact Factor: SJIF: 5.995

Available Online at www.journalijcar.org

Volume 6; Issue 5; May 2017; Page No. 3740-3746

DOI: http://dx.doi.org/10.24327/ijcar.2017.3746.0360

Research Article

\title{
ANTIMICROBIAL EFFICACY OF ENDODONTIC IRRIGANTS AND COMBINATION SURFACTANT REGIMENS ON ENTEROCOCCUS FAECALIS. AN IN VITRO MICROBIOLOGICAL STUDY
}

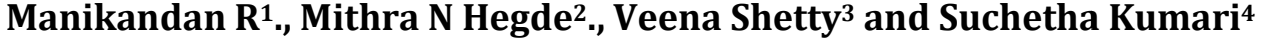 \\ ${ }^{1}$ Department Of Conservative Dentistry \& Endodontics PMS College of Dental Science and Research \\ 2Department Of Conservative Dentistry \& Endodontics ABSMIDS, NITTE University \\ ${ }^{3}$ Department Of Microbiology ABSMIDS, NITTE University \\ ${ }^{4}$ Department Of Biochemistry ABSMIDS, NITTE University
}

\section{A R R T I C L E I N F}

\section{Article History:}

Received $14^{\text {th }}$ February, 2017

Received in revised form $12^{\text {th }}$ March, 2017

Accepted $5^{\text {th }}$ April, 2017

Published online $28^{\text {th }}$ May, 2017

\section{Key words:}

Endodontic irrigants, Surfactants, E.faecalis, Combination regimens, Disc diffusion

\begin{abstract}
A B S T R A C T
Background: Disinfection of the root canal system is primarily achieved by endodontic irrigants. Although most products contain surfactants which claim to enhance the antimicrobial properties of the irrigants no current data exists. objective: Thus the purpose of this study was to evaluate the antimicrobial efficacy of endodontic irrigants and surfactant irrigation regimens with MTAD on E.faecalis. Methods: Primary irrigants such as $\mathrm{NaOCl}, \mathrm{CHX}$, IKI were prepared at concentrations of $5 \%, 2.5 \%, 2 \% \& 1 \%$; while MTAD served as the control group. Surfactants such as Cetrimide (CTR) and Sodium Dodecyl Sulfate (SDS) were prepared at concentrations of $0.25 \%, 0.5 \%, 1 \% \& 2 \%$. The modified Kirby - Bauer method was used to evaluate the antimicrobial efficacy. The data obtained was analyzed by Anova and Bonferroni multiple comparison test. Results: Only IKI (5\%) was non significant $(\mathrm{p}>0.5)$ with MTAD. MTAD was statistically significant $(\mathrm{p}<0.5)$ with CTR \& SDS. MTAD was statistically significant $(\mathrm{p}<0.5)$ over combination irrigant regimens $(2 \% \mathrm{CHX}+0.5 \% \mathrm{CTR} \& 2 \% \mathrm{CHX}+1 \% \mathrm{SDS})$. Conclusion: Surfactants CTR \& SDS in combination with CHX showed significant antimicrobial activity; however MTAD proved to be superior.
\end{abstract}

Copyright $@ 2017$ Manikandan $\mathbf{R}$ et al. This is an open access article distributed under the Creative Commons Attribution License, which permits unrestricted use, distribution, and reproduction in any medium, provided the original work is properly cited.

\section{INTRODUCTION}

Microorganisms are the primary cause for both pulpal and periapical diseases. Endodontic practice involves a systematic procedure primarily aimed to achieve the highest possible success rate by eliminating the potential causes ${ }^{1}$. Cleaning and disinfection procedure plays one of the essential steps that involves mechanical instrumentation and use of endodontic irrigants ${ }^{2}$. Although with the paradigm shift from multivisit to single visit endodontic procedure; mechanical instrumentation focuses on the primary root canal system, leaving the ramifications (lateral, accessory canals) untouched; which harbor microorganisms ${ }^{3}$. Thus the irrigants play a vital role to disinfect the complex root canal system ${ }^{4}$.

An ideal irrigant should have potent antimicrobial activity, dissolving of remaining pulp tissues with no systemic hazards, reducing instrument friction during mechanical preparation and availability ${ }^{5}$. Sodium hypochlorite $(\mathrm{NaOCl})$ has widely been accepted as a root canal irrigant since its first reported use by Walker in $1936^{6}$.

*Corresponding author: Manikandan R

Department Of Conservative Dentistry \& Endodontics PMS

College of Dental Science and Research
It mainly acts as a potent antimicrobial agent and an effective organic solvent for vital, necrotic and fixed tissue ${ }^{7}$. Despite its fulfillment of certain desirable properties including availability and low cost; it has unpleasant taste, tendency to bleach clothes and it is potentially corrosive. Concern regarding its noxious effects arises if concentrated solutions were inadvertently forced into the periapical tissues during irrigation or leaked through the rubber dam $^{8}$. Besides, some controversies do exist with regard to its antimicrobial activity at lower concentrations; an attempt to reduce its toxicity ${ }^{9-11}$.

Chlorhexidine gluconate $(\mathrm{CHX})$ is routinely used in dentistry as a mouth rinse in the prevention and treatment of periodontal disease and caries ${ }^{12}$. It has potent and substantive antimicrobial activity (SAA) against some resistant bacteria such as Enterococcus faecalis ${ }^{13}$; and lesser cytotoxic than $\mathrm{NaOCl}^{14}$. CHX in endodontics serves as a potent root canal irrigant and medicament ${ }^{15}$. However, the use of CHX has been restricted serving as an adjunct irrigant or as a final rinse rather than a substitute for $\mathrm{NaOCl}^{16}$. $\mathrm{CHX}$ cannot dissolve organic/necrotic tissue remnants and its lesser antibacterial activity against Gram-negative rather than Gram-positive bacteria ${ }^{17}$. Although $\mathrm{CHX}$ has been commonly held as less toxic than $\mathrm{NaOCl}$, it has been reported to cause irritation to 
the $\operatorname{skin}^{18}$. In addition, its cytotoxic effects on human osteoblasts might indicate its ability to impair the regenerative potential of the periapical tissues ${ }^{19}$. Although infected root canals are polymicrobial; Gram-negative bacteria are predominantly found in primary endodontic infections ${ }^{20}$. Enterococcus faecalis (E. faecalis) is a Gram positive facultative anaerobic bacterium found in the human normal flora $^{21}$. In endodontics, E. faecalis is rarely present in primary apical periodontitis, and is dominant in the microbial ecosystem of persistent periradicular lesions after root canal treatment $^{22}$. It is ecologically tolerant and has the ability to survive harsh conditions as it exhibits considerable genetic polymorphisms and can bind to dentin and resist the action of calcium hydroxide, especially when a high $\mathrm{pH}$ is not maintained $^{23}$.

The scope of irrigants has widened in current research and far outplays the basic functions that were once a requisite. Sodium hypochlorite $(\mathrm{NaOCl})$, chlorhexidine $(\mathrm{CHX})$, Iodine Potassium Iodide (IKI) and ethylene diamine tetra acetic acid (EDTA) are the commonly used endodontic irrigants along with normal saline (NS) ${ }^{24}$. With newer endodontic irrigants such as MTAD (mixture of tetracycline isomer, acid \& detergent), cetrexidin $(0.2 \%$ chlorhexidine gluconate $+0.2 \%$ cetrimide), chlor-xtra $(6 \% \mathrm{NaOCl}+$ surface modifiers $)$ etc currently available in the market; one can only assume that none of the irrigants have all the ideal requirements and the search for a combination regimen is an emerging trend ${ }^{25}$. Disinfection gains major importance in infected canals which are polymicrobial. Enterococcus faecalis is resistant to most irrigants even at higher concentrations ${ }^{26}$.

The term surfactant was coined by Antara products in 1950 . Surfactants are usually organic compounds that are amphiphilic, meaning they contain both hydrophobic groups (their tails) and hydrophilic groups (their heads). Therefore, they are soluble in both organic solvents and water ${ }^{27}$.

Surfactants are surface active agents that enhance the wetting ability of the irrigants by reducing the surface tension; thereby promoting their close contact with the microorganisms to exert their antimicrobial effect ${ }^{28}$. Thus the purpose of this study was to evaluate the antimicrobial efficacy of endodontic irrigants and their surfactant regimens on E.faecalis

\section{MATERIALS AND METHODS}

\section{Place of study and bacterial strain used}

The present study was performed in the Central Research laboratory, A.B Shetty Memorial Institute of Dental Sciences. E. faecalis ATCC 29212 (Himedia) was used in the study. Bacteria were sub-cultured from the stock culture. The suspension culture of the test microorganism was prepared in Brain Heart Infusion broth.

\section{Standardization of microorganisms}

Brain Heart Infusion broth was inoculated with the test microorganism and incubated for 6 to 7 hours to get the density of microorganism equal to $0.5 \mathrm{McFarland}$ constant which is equivalent to $1.5 \times 10^{8} \mathrm{CFU} / \mathrm{ml}$. Then $1 \mathrm{ml}$ of each suspension culture was transferred to the required number of sterile screw cap tubes (HIMEDIA). All procedures were performed using sterilized instruments and materials.

\section{Irrigants and surfactants used}

In this study $\mathrm{NaOCl}$ (PrevestDenpro Limited, 5\%), CHX (Sigma, 20\% aqueous solution), 5\% IKI was prepared by dissolving $5 \mathrm{~g}$ of iodine (Merck) and $10 \mathrm{~g}$ of potassium iodide (Himedia) in $94 \mathrm{~mL}$ of physiological saline. Concentrations $1 \%, 2 \%, 2.5 \%$ and $5 \%$ of the irrigants were prepared for the study. Surfactants cetrimide (CTR) - Himedia, sodium dodecyl sulfate (SDS)-Merck were prepared in concentrations ranging from $0.25 \%-2 \%$. Biopure MTAD (Tulsa, Densply) was used as per manufacturer's instructions. All prepared irrigants were stored in sterile bottles.

\section{Antimicrobial susceptibility (disc diffusion) test}

The modified Kirby-Bauer method was followed to check the antimicrobial efficacy. Using a Sterile swab (Himedia); E. faecalis (ATCC 29212) cultures were evenly spread on the solidified $20 \mathrm{ml}$ of Mueller Hinton Agar plates. This was followed by placing Sterile disc (Himedia) with known volume of solutions (control, primary irrigants, surfactants \& combination regimens). In this method $20 \mu 1$ of the solution was added on each disc. Six replicates for each solution were kept. Then petriplates were placed in an incubator at $37^{\circ} \mathrm{C}$. After the overnight incubation the zone of inhibition was measured.

Statistical analysis was done by means of a one way ANOVA and Bonfferroni multiple comparison test

\section{RESULTS}

In the primary irrigant group only IKI (5\%) was statistically non significant $(\mathrm{p}>0.5)$ with MTAD (control 100\%). MTAD was found to be statistically significant $(p<0.5)$ and showed greater zones of inhibition than other irrigants and concentrations tested (Table I-III).

In the surfactant group CTR and SDS showed zones of inhibition varying from $0.25 \%-2 \%$; however $0.25 \%$ SDS showed no antimicrobial activity. MTAD was statistically significant $(p<0.5)$ and showed greater zones of inhibition than CTR and SDS at any test dose. 0.5\% CTR was statistically not significant $(\mathrm{p}>0.5)$ with $1 \%$ CTR. $1 \%$ SDS was statistically not significant $(p>0.5)$ with $2 \%$ SDS. $0.5 \%$ CTR and 1\% SDS showed the same antimicrobial activity (Table IV-V).

No synergistic antimicrobial activity was found with $\mathrm{NaOCl}$ \& IKI with CTR \& SDS at any test concentrations and thus were excluded. Combination irrigant regimens with $\mathrm{CHX}$ $(2 \% \mathrm{CHX}+0.5 \% \mathrm{CTR} \& 2 \% \mathrm{CHX}+1 \% \mathrm{SDS})$ were found to experimentally significant; however MTAD was statistically significant $(\mathrm{p}<0.5)$ than the above. MTAD proved to be superior and showed greater antimicrobial activity (Table VI).

Table I A Mean zones of inhibition of $\mathrm{NaOCl}$ obtained with E. faecalis ATCC 29212

ATCC 29212

Group: $\mathrm{NaOCl}$

\begin{tabular}{|c|c|c|c|c|c|c|c|}
\hline & \multirow[t]{3}{*}{$\mathbf{N}$} & \multirow[t]{3}{*}{ Mean } & \multirow[t]{3}{*}{$\begin{array}{c}\text { Std. } \\
\text { Deviation }\end{array}$} & \multicolumn{2}{|c|}{$\begin{array}{l}\text { 95\% Confidence } \\
\text { Interval for Mean }\end{array}$} & \multirow[t]{2}{*}{ ANOVA F } & \multirow[t]{3}{*}{$\mathbf{p}$} \\
\hline & & & & Lower & Upper & & \\
\hline & & & & Bound & Bound & & \\
\hline $5.00 \%$ & 6 & 13.92 & .204 & 13.70 & 14.13 & 476.975 & .000 \\
\hline $2.500 \%$ & 6 & 12.67 & .516 & 12.12 & 13.21 & & HS \\
\hline $2.00 \%$ & 6 & 11.33 & .516 & 10.79 & 11.88 & & \\
\hline $1.00 \%$ & 6 & 10.67 & .516 & 10.12 & 11.21 & & \\
\hline $\begin{array}{c}\text { Control } \\
100 \%\end{array}$ & 6 & 25.50 & 1.225 & 24.21 & 26.79 & & \\
\hline Total & 30 & 14.82 & 5.587 & 12.73 & 16.90 & & \\
\hline
\end{tabular}


Table I B Intragroup comparison of $\mathrm{NaOCl}$ obtained with E. faecalis ATCC 29212

Dependent Variable: ATCC 29212
Bonferroni

Multiple Comparisons

Group: $\mathrm{NaOCl}$

\begin{tabular}{|c|c|c|c|c|}
\hline (I) Concentration & (J) Concentration & $\begin{array}{c}\text { Mean } \\
\text { Difference } \\
(1-J)\end{array}$ & Std. Error & $\mathrm{p}$ \\
\hline \multirow[t]{4}{*}{$5.00 \%$} & $2.500 \%$ & $1.250^{*}$ & .395 & .041 \\
\hline & $2.00 \%$ & $2.583^{\star}$ & .395 & .000 \\
\hline & $1.00 \%$ & $3.250^{*}$ & .395 & .000 \\
\hline & Control $100 \%$ & $-11.583^{*}$ & 395 & .000 \\
\hline \multirow[t]{4}{*}{$2.500 \%$} & $5.00 \%$ & $-1.250^{*}$ & .395 & .041 \\
\hline & $2.00 \%$ & $1.333^{*}$ & .395 & .024 \\
\hline & $1.00 \%$ & $2.000^{*}$ & .395 & .000 \\
\hline & Control $100 \%$ & $-12.833^{*}$ & .395 & .000 \\
\hline \multirow[t]{4}{*}{$2.00 \%$} & $5.00 \%$ & $-2.583^{\star}$ & .395 & .000 \\
\hline & $2.500 \%$ & $-1.333^{*}$ & .395 & .024 \\
\hline & $1.00 \%$ & .667 & .395 & 1.000 \\
\hline & Control $100 \%$ & $-14.167^{\star}$ & .395 & .000 \\
\hline \multirow[t]{4}{*}{$1.00 \%$} & $5.00 \%$ & $-3.250^{*}$ & .395 & .000 \\
\hline & $2.500 \%$ & $-2.000^{*}$ & .395 & .000 \\
\hline & $2.00 \%$ & -.667 & .395 & 1.000 \\
\hline & Control $100 \%$ & $-14.833^{\star}$ & .395 & .000 \\
\hline \multirow[t]{4}{*}{ Control $100 \%$} & $5.00 \%$ & $11.583^{*}$ & .395 & .000 \\
\hline & $2.500 \%$ & $12.833^{*}$ & .395 & .000 \\
\hline & $2.00 \%$ & $14.167^{\star}$ & .395 & .000 \\
\hline & $1.00 \%$ & $14.833^{*}$ & .395 & .000 \\
\hline
\end{tabular}

Table II A Mean zones of inhibition of CHX obtained with E. faecalis ATCC 29212

ATCC 29212

Group: CHX

\begin{tabular}{|c|c|c|c|c|c|c|c|}
\hline & \multirow[t]{3}{*}{$\mathbf{N}$} & \multirow[t]{3}{*}{ Mean } & \multirow[t]{3}{*}{$\begin{array}{c}\text { Std. } \\
\text { Deviation }\end{array}$} & \multicolumn{2}{|c|}{ 95\% Confidence } & ANOVA $F$ & $\mathbf{F}$ \\
\hline & & & & Lower & Upper & & \\
\hline & & & & Bound & Bound & & \\
\hline $5.00 \%$ & 6 & 15.92 & .204 & 15.70 & 16.13 & 380.541 & .000 \\
\hline $2.500 \%$ & 6 & 14.33 & .516 & 13.79 & 14.88 & & HS \\
\hline $2.00 \%$ & 6 & 13.92 & .204 & 13.70 & 14.13 & & \\
\hline $1.00 \%$ & 6 & 12.67 & .516 & 12.12 & 13.21 & & \\
\hline $\begin{array}{c}\text { Control } \\
100 \%\end{array}$ & 6 & 25.50 & 1.225 & 24.21 & 26.79 & & \\
\hline Total & 30 & 16.47 & 4.752 & 14.69 & 18.24 & & \\
\hline
\end{tabular}

Table II B Intragroup comparison of CHX obtained with E. faecalis ATCC 29212

Multiple Comparisons

Dependent Variable: ATCC 29212

Bonferroni

\begin{tabular}{|c|c|c|c|c|}
\hline (I) Concentration & (J) Concentration & $\begin{array}{c}\text { Mean } \\
\text { Difference } \\
(I-J)\end{array}$ & Std. Error & $\mathrm{p}$ \\
\hline \multirow[t]{4}{*}{$5.00 \%$} & $2.500 \%$ & $1.583^{*}$ & .376 & .003 \\
\hline & $2.00 \%$ & $2.000^{*}$ & .376 & .000 \\
\hline & $1.00 \%$ & $3.250^{*}$ & .376 & .000 \\
\hline & Control $100 \%$ & $-9.583^{*}$ & .376 & .000 \\
\hline \multirow[t]{4}{*}{$2.500 \%$} & $5.00 \%$ & $-1.583^{*}$ & .376 & .003 \\
\hline & $2.00 \%$ & .417 & .376 & 1.000 \\
\hline & $1.00 \%$ & $1.667^{*}$ & .376 & .002 \\
\hline & Control $100 \%$ & $-11.167^{*}$ & .376 & .000 \\
\hline \multirow[t]{4}{*}{$2.00 \%$} & $5.00 \%$ & $-2.000^{*}$ & .376 & .000 \\
\hline & $2.500 \%$ & -.417 & .376 & 1.000 \\
\hline & $1.00 \%$ & $1.250^{*}$ & .376 & .027 \\
\hline & Control $100 \%$ & $-11.583^{*}$ & .376 & .000 \\
\hline \multirow[t]{4}{*}{$1.00 \%$} & $5.00 \%$ & $-3.250^{*}$ & .376 & .000 \\
\hline & $2.500 \%$ & $-1.667^{*}$ & .376 & .002 \\
\hline & $2.00 \%$ & $-1.250^{*}$ & .376 & .027 \\
\hline & Control $100 \%$ & $-12.833^{*}$ & .376 & .000 \\
\hline \multirow[t]{4}{*}{ Control $100 \%$} & $5.00 \%$ & $9.583^{*}$ & .376 & .000 \\
\hline & $2.500 \%$ & $11.167^{*}$ & .376 & .000 \\
\hline & $2.00 \%$ & $11.583^{*}$ & .376 & .000 \\
\hline & $1.00 \%$ & $12.833^{*}$ & .376 & .000 \\
\hline
\end{tabular}

*. The mean difference is significant at the .05 level.
Table III A Mean zones of inhibition of IKI obtained with E. faecalis ATCC 29212

ATCC 29212

Group: IKI

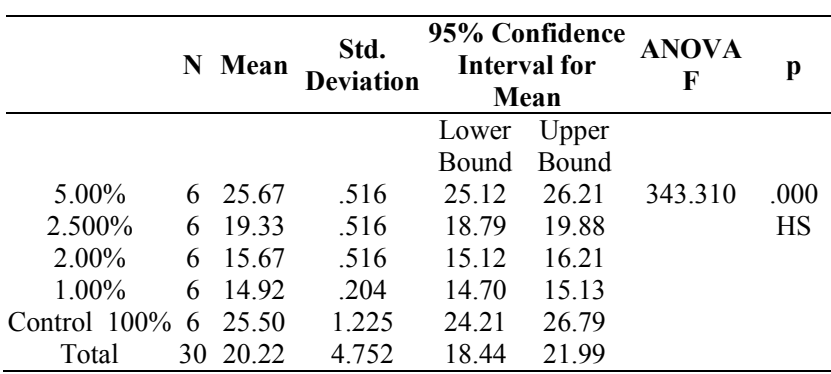

Table III B Intragroup comparison of IKI obtained with E. faecalis ATCC 29212

Multiple Comparisons

Dependent Variable: ATCC 29212

Bonferroni

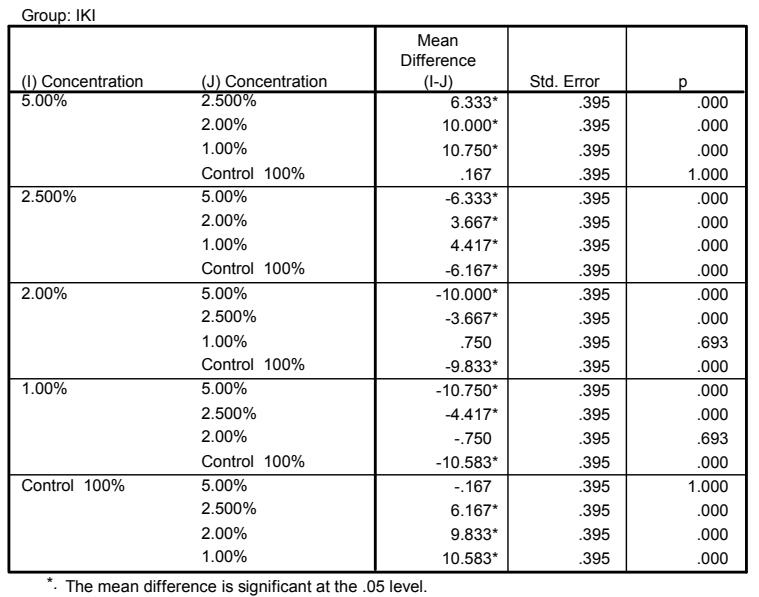

Table IV A Mean zones of inhibition of CTR obtained with E. faecalis ATCC 29212

ATCC 29212

Secondary: CTR

\begin{tabular}{cccccccc}
\hline & N & Mean & $\begin{array}{c}\text { Std. } \\
\text { Deviation }\end{array}$ & \multicolumn{2}{c}{$\begin{array}{c}\text { 95\% Confidence } \\
\text { Interval for Mean }\end{array}$} & $\begin{array}{c}\text { ANOV } \\
\text { A F }\end{array}$ & p \\
\hline & & & & Lower & Upper & & \\
$.25 \%$ & 6 & 7.67 & .516 & 7.12 & 8.21 & 613.750 .000 \\
$.50 \%$ & 6 & 9.67 & .516 & 9.12 & 10.21 & HS \\
$1.0 \%$ & 6 & 10.67 & .516 & 10.12 & 11.21 & \\
$2.0 \%$ & 6 & 12.17 & .408 & 11.74 & 12.60 & \\
control 100.0\% & 6 & 25.50 & 1.225 & 24.21 & 26.79 & \\
Total & 30 & 13.13 & 6.495 & 10.71 & 15.56 & \\
\hline
\end{tabular}

Table IV B Intragroup comparison of CTR obtained with E. faecalis ATCC 29212

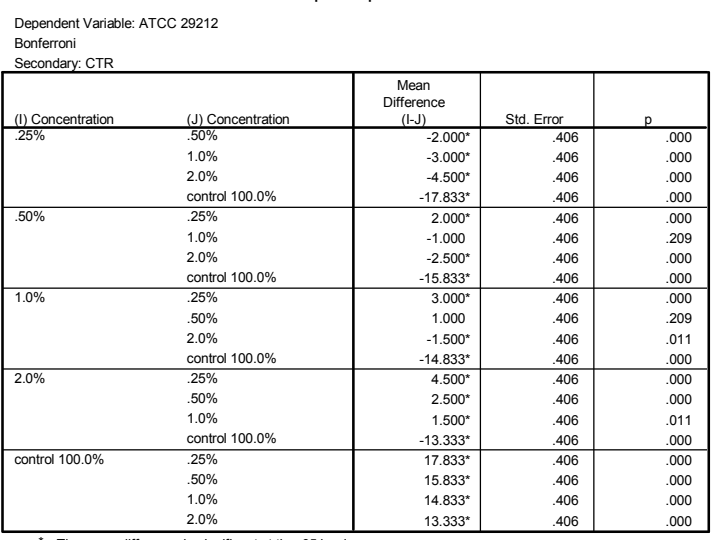


Table V A Mean zones of inhibition of SDS obtained with E. faecalis ATCC 29212

ATCC 29212

Secondary: SDS

\begin{tabular}{cccccccc}
\hline & $\mathbf{N}$ & Mean & $\begin{array}{c}\text { Std. } \\
\text { Deviation }\end{array}$ & $\begin{array}{c}95 \% \text { Confidence } \\
\text { Interval for Mean }\end{array}$ & ANOVA F & p \\
\hline \multicolumn{7}{c}{$\begin{array}{c}\text { Lower } \\
\text { Bound }\end{array}$} & Upper Bound \\
$.25 \%$ & 6 & .00 & .000 & .00 & .00 & 1155.568 & .000 \\
$.50 \%$ & 6 & 8.67 & .516 & 8.12 & 9.21 & & HS \\
$1.0 \%$ & 6 & 9.67 & .516 & 9.12 & 10.21 & & \\
$2.0 \%$ & 6 & 10.17 & .408 & 9.74 & 10.60 & & \\
control & 6 & 25.50 & 1.225 & 24.21 & 26.79 & & \\
$100.0 \%$ & 6 & & & & & \\
Total & 30 & 10.80 & 8.397 & 7.66 & 13.94 & & \\
\hline
\end{tabular}

Table V B Intragroup comparison of SDS obtained with E. faecalis ATCC 29212

Multiple Comparisons

\begin{tabular}{|c|c|c|c|c|}
\hline \multicolumn{5}{|c|}{ Multiple Comparisons } \\
\hline \multirow{3}{*}{\multicolumn{5}{|c|}{$\begin{array}{l}\text { Dependent Variable: ATCC } 29212 \\
\text { Bonferroni } \\
\text { Secondary: SDS }\end{array}$}} \\
\hline & & & & \\
\hline & & & & \\
\hline (I) Concentration & (J) Concentration & $\begin{array}{c}\text { Mean } \\
\text { Difference } \\
(I-J)\end{array}$ & Std. Error & $p$ \\
\hline \multirow[t]{4}{*}{$.25 \%$} & $.50 \%$ & $-8.667^{*}$ & .383 & .000 \\
\hline & $1.0 \%$ & $-9.667^{*}$ & .383 & .000 \\
\hline & $2.0 \%$ & $-10.167^{*}$ & .383 & .000 \\
\hline & control $100.0 \%$ & $-25.500^{*}$ & .383 & .000 \\
\hline \multirow[t]{4}{*}{$.50 \%$} & $.25 \%$ & $8.667^{*}$ & .383 & .000 \\
\hline & $1.0 \%$ & -1.000 & .383 & .150 \\
\hline & $2.0 \%$ & $-1.500^{*}$ & .383 & .006 \\
\hline & control $100.0 \%$ & $-16.833^{*}$ & .383 & .000 \\
\hline \multirow[t]{4}{*}{$1.0 \%$} & $.25 \%$ & $9.667^{*}$ & .383 & .000 \\
\hline & $.50 \%$ & 1.000 & .383 & .150 \\
\hline & $2.0 \%$ & -.500 & .383 & 1.000 \\
\hline & control $100.0 \%$ & $-15.833^{*}$ & .383 & .000 \\
\hline \multirow[t]{4}{*}{$2.0 \%$} & $.25 \%$ & $10.167^{*}$ & .383 & .000 \\
\hline & $.50 \%$ & $1.500^{*}$ & .383 & .006 \\
\hline & $1.0 \%$ & .500 & .383 & 1.000 \\
\hline & control $100.0 \%$ & $-15.333^{*}$ & .383 & .000 \\
\hline \multirow[t]{4}{*}{ control $100.0 \%$} & $.25 \%$ & $25.500^{*}$ & .383 & .000 \\
\hline & $.50 \%$ & $16.833^{*}$ & .383 & .000 \\
\hline & $1.0 \%$ & $15.833^{*}$ & .383 & .000 \\
\hline & $2.0 \%$ & $15.333^{*}$ & .383 & .000 \\
\hline
\end{tabular}

Table VI A Intergroup comparison of mean zones of inhibition of combination regimens with MTAD

Combination Regimen

\begin{tabular}{|c|c|c|c|c|c|c|c|c|c|}
\hline & & \multirow[b]{2}{*}{$\mathrm{N}$} & \multirow[b]{2}{*}{ Mean } & \multirow[b]{2}{*}{ Std. Deviation } & \multirow[b]{2}{*}{ Std. Error } & \multicolumn{2}{|c|}{$\begin{array}{l}\text { 95\% Confidence Interval } \\
\text { Mean }\end{array}$} & \multirow[b]{2}{*}{ ANOVA $\mathrm{F}$} & \multirow[b]{2}{*}{$\mathrm{P}$} \\
\hline & & & & & & Low er Bound & Upper Bound & & \\
\hline \multirow[t]{4}{*}{29212.00} & $2 \% \mathrm{CHX}+0.5 \% \mathrm{CTR}$ & 4 & 14.7500 & .28868 & .14434 & 14.2907 & 15.2093 & \multirow{4}{*}{\multicolumn{2}{|c|}{$\begin{array}{c}285.558 \begin{array}{c}.000 \\
\text { hs }\end{array} \\
\end{array}$}} \\
\hline & $2 \% \mathrm{CHX}+1 \% \mathrm{SDS}$ & 4 & 14.2500 & .28868 & .14434 & 13.7907 & 14.7093 & & \\
\hline & MTAD & 6 & 25.5000 & 1.22474 & .50000 & 24.2147 & 26.7853 & & \\
\hline & Total & 14 & 19.2143 & 5.70666 & 1.52517 & 15.9194 & 22.5092 & & \\
\hline
\end{tabular}

Table VI B Intergroup comparison of combination regimens obtained with $E$. faecalis ATCC 29212

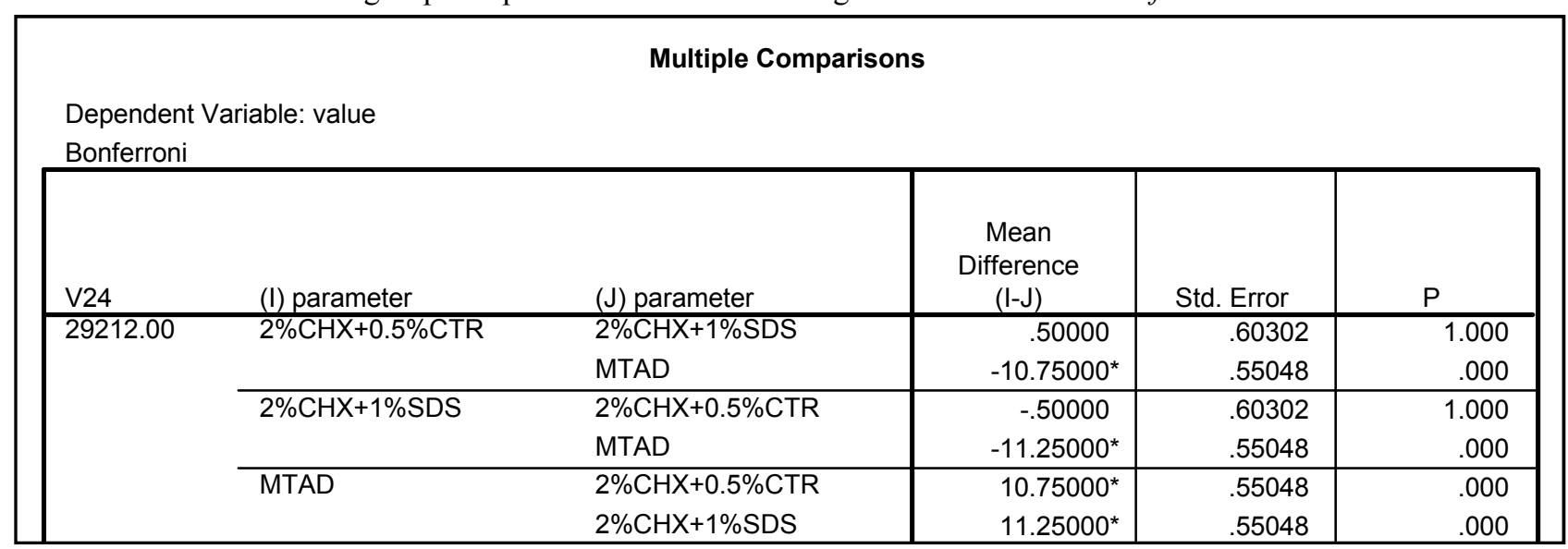

*The mean difference is significant at the .05 level. 
Torabinejad et al stated MTAD possessed antimicrobial effect even after dilution; while $5.25 \% \mathrm{NaOCl}$ demonstrated lesser zones of inhibition when diluted ${ }^{35}$.

Davis et al also confirmed that there was no difference between $5.25 \% \mathrm{NaOCl}$ and $2 \% \mathrm{CHX}^{36}$. The results of our study was not in accordance with Portenier et al, who compared the antimicrobial activity of MTAD to that of chlorhexidine digluconate with or without detergent in the presence or absence of dentine or bovine serum albumin. MTAD and chlorhexidine were equally effective in killing $E$. faecalis. The presence of dentine or bovine serum albumin delayed killing by both medicaments ${ }^{37}$.

The combination of $\mathrm{NaOCl}$ with surfactants did not yield any synergestic antimicrobial activity and was accordance with Jungbluth who stated chlor-xtra $(6 \% \mathrm{NaOCl}+$ surface modifiers) has no unique features other than its price; and reduced surface tension with surfactants did not result in greater soft tissue dissolution by $\mathrm{NaOCl}^{38}$. Giardino et al stated that cetrexedin $(0.2 \% \mathrm{CTR}+0.2 \% \mathrm{CHX})$ has the lowest surface tension value; thus increasing the intimate contact of irrigant solution with the dentinal walls, thus permitting deeper penetration of the irrigant ${ }^{39}$. Baca et al stated that $2 \%$ $\mathrm{CHX}+0.2 \% \mathrm{CTR}$ would be an effective alternative as final irrigation regimen given its antimicrobial action over time ${ }^{40}$. IKI with surfactant combinations yielded a lesser antimicrobial activity as compared with IKI alone. This could be due to interaction of IKI with the organic surfactants and resulting in precipitate formation ${ }^{41}$.

Cetrimide (CTR) is a cationic quaternary ammonium compound with antimicrobial ability, stability and solubility in water. The cationic environment of the molecule encourages linking with anionic compound at the bacterial surface and is capable of altering the cytoplasmic membrane integrity. Once the cytoplasmic membrane is damaged, alteration of the functions involving cytoplasmic membrane permeability may be observed. Inactivation of the enzymes of cytoplasmic membrane results in protein denaturation and cell death $^{42}$.

CTR is non cytotoxic and has been used as endodontic irrigant $^{43}$. $0.5 \%$ CTR alone showed the same antimicrobial effect as primary irrigants $(2.5 \% \mathrm{NaOCl}, 2 \% \mathrm{CHX} \& 2 \%$ IKI $)^{34}$; and hence was taken as effective concentration for the combination regimen.

SDS represent a potentially effective topical microbicide, which can also inhibit and possibly prevent infection by various enveloped and non-enveloped viruses such as the Herpes simplex viruses, HIV, and the Semliki Forest Virus $^{44}$. SDS is not carcinogenic when either applied directly to skin or consumed. SDS is an anionic alkyl sulfate; has the properties of low surface tension, can solubilise proteins, increase lipopolysaccharides (LPS) disaggregation and inhibit bacterial coaggreagation; which could account for its antimicrobial activity ${ }^{45}$. 1\% SDS had the same antimicrobial activity as that of $0.5 \% \mathrm{CTR}$ and was chosen for the combination regimen.

MTAD contains 3\% doxycycline (tetracycline isomer) $150 \mathrm{mg} / 5 \mathrm{ml}$ that potentiates its antibacterial activity. In addition it has $4.25 \%$ Citricacid, $0.5 \%$ polysorbate 80 (surfactant), which could enhance its antibacterial activity. Gram positive microorganisms are more susceptible to lower concentrations of tetracycline (doxycycline in MTAD) than are Gram negative ones ${ }^{46}$. The poylysorbate 80 (surfactant) used in the irrigant could enhance the wetting ability; thereby exerting greater antibacterial activity for disinfection ${ }^{47}$.

Despite the common application of the agar diffusion method, many factors, other than the actual antibacterial activity of the tested material, might affect the reliability and reproducibility of the agar diffusion method. These factors include the chemical agent's formulation (liquid or gel), its molecular size, solubility and diffusion ability of the material through the agar medium, contact between the test material and the gel, inoculum density, agar viscosity, storage conditions of the agar plates and incubation time. Furthermore, the soaking and application procedures might also affect the diffusion of the material into the agar ${ }^{48}$.

To conclude the combination regimens $2 \% \mathrm{CHX}$ with $0.5 \%$ CTR and 1\% SDS showed experimentally significant results and further clinical trials are required to justify the role of surfactants from the data obtained from the current study.

\section{References}

1. Baugh D, Wallace J. The role of apical instrumentation in root canal treatment: A review of the literature. $J$ Endod 2005;31:333-40

2. Mohammadi Z, Abbott PV. Antimicrobial substantivity of root canal irrigants and medicaments: A review. Aust Endod J 2009; 35:131-9.

3. Gomes NV et al. Recovery of E. faecalis after single or multiple visit root canal treatments carried out in infected teeth ex vivo. Int Endod J 2005; 38: 697-704.

4. Filho EDG et al. In vitro evaluation of the effectiveness of the chemomechanical preparation against Enterococcus faecalis after single or multiplevisit root canal treatment. Braz Oral Res 2007; 21(4):308-13.

5. Zehnder M. Root canal irrigants. J Endod 2006; 32:389-98.

6. Sassone LM, Fidel RA, Murad CF, Fidel SR, Hirata R Jr. Antimicrobial activity of sodium hypochlorite and chlorhexidine by two different tests. Aust Endod J 2008; 34:19-24.

7. Gomes BP, Ferraz CC, Vianna ME, Berber VB, Teixeira FB, Souza-Filho FJ. In vitro antimicrobial activity of several concentrations of sodium hypochlorite and chlorhexidine gluconate in the elimination of Enterococcus faecalis. Int Endod $J$ 2001;34:424-8

8. Hülsmann M, Rödig T, Nordmeyer S. Complications during root canal irrigation. Endod Top 2009; 16:2763.

9. Carson KR, Goodell GG, McClanahan SB. Comparison of the antimicrobial activity of six irrigants on primary endodontic pathogens. J Endod, 2005; 31:471-3.

10. Berber VB, Gomes BP, Sena NT, Vianna ME, Ferraz CC, Zaia AA, et al. Efficacy of various concentrations of $\mathrm{NaOCl}$ and instrumentation techniques in reducing Enterococcus faecalis within root canals and dentinal tubules. Int Endod J 2006;39:10-7

11. Câmara AC, de Albuquerque MM, Aguiar CM, de Barros Correia AC. In vitro antimicrobial activity of $0.5 \%, 1 \%$, and $2.5 \%$ sodium hypochlorite in root 
canals instrumented with the ProTaper Universal system. Oral Surg Oral Med Oral Pathol Oral Radiol Endod 2009; 108:e55-61.

12. Cervone F, Tronstad L, Hammond B. Antimicrobial effect of chlorhexidine in a controlled release delivery system. Endod Dent Traumatol 1990; 1:33-6.

13. Leonardo MR, Tanomaru Filho M, Silva LA, Nelson Filho $\mathrm{P}$, Bonifácio $\mathrm{KC}$, et al. In vivo antimicrobial activity of $2 \%$ chlorhexidine used as a root canal irrigating solution. J Endod 1999; 25:167-71.

14. Kuruvilla JR, Kamath MP. Antimicrobial activity of $2.5 \%$ sodium hypochlorite and $0.2 \%$ chlorhexidine gluconate separately and combined, as endodontic irrigants. J Endod 1998; 24:472-6.

15. Ferraz CC, Gomes BP, Zaia AA, Teixeira FB, SouzaFilho FJ. In vitro assessment of the antimicrobial action and the mechanical ability of chlorhexidine gel as an endodontic irrigant. J Endod 2001; 27:452-5.

16. Naenni N, Thoma K, Zehnder M. Soft tissue dissolution capacity of currently used and potential endodontic irrigants. J Endod 2004; 30:785-7.

17. Wang CS, Arnold RR, Trope M, Teixeira FB. Clinical efficiency of $2 \%$ chlorhexidine gel in reducing intracanal bacteria. $J$ Endod 2007; 33:1283-9.

18. Foulkes DM. Some toxicological observations on chlorhexidine. J Periodontal Res Suppl 1973;12:55-60

19. Lee $\mathrm{TH}, \mathrm{Hu} \mathrm{CC}$, Lee SS, Chou MY, Chang YC. Cytotoxicity of chlorhexidine on human osteoblastic cells is related to intracellular glutathione levels. Int Endod J 2010; 43:430-5.

20. Mohammadi Z, Abbott PV. Antimicrobial substantivity of root canal irrigants and medicaments: A review. Aust Endod J 2009; 35:131-9.

21. Portenier I, Waltimo TMT and Haapasalo M. Enterococcus faecalis - the root canal survivor and 'star' in post treatment disease. Endod Top 2003; 6:135-59.

22. Stuart CH, Schwartz SA, Beeson TJ, Owatz CB. Enterococcus faecalis: Its role in root canal treatment failure and current concepts in retreatment. $J$ Endod 2006; 32:93-8.

23. Siqueira JF Jr, Guimaraes-Pinto T, Rocas IN. Effects of chemomechanical preparation with $2.5 \%$ sodium hypochlorite and intra-canal medication with calcium hydroxide on cultivable bacteria in infected root canals. J Endod 2007; 33:800-5.

24. Siqueira JF Jr, Batista MM, Fraga RC, de Uzeda M. Antibacterial effects of endodontic irrigants on blackpigmented gram-negative anaerobes and facultative bacteria. J Endod 1998; 24:414-6.

25. Mamatha Y, Ballal S, Gopikrishna V, Kandaswamy D. Comparison of sodium hypochlorite and EDTA irrigants with an indigenous solution as an alternative to MTAD. J Conserv Dent 2006; 9(1):48-52.

26. Ayhan H, Sultan N, Cirak M, Ruhi MZ, Bodur H. Antimicrobial effects of various endodontic irrigants on selected microorganisms. Int Endod J 1999; 32:99102 .

27. Newton BA. The mechanism of the bactericidal action of surface active compounds: A Summary. $J$ Appl Bacteriol 1960; 23:345-349.
28. Hotchkiss RD. The nature of the bactericidal action of surface active agents. Am N Y Acad Sci 1946; 46:479492.

29. Luddin N, Ahmed HM. The antibacterial activity of sodium hypochlorite and chlorhexidine against Enterococcus faecalis: A review on agar diffusion and direct contact methods. J Conserv Dent 2013; 16:9-16.

30. Siqueira JF Jr, Alves FR, Almeida BM, de Oliveira JC, Rocas IN. Ability of chemomechanical preparation with either rotary instruments or self-adjusting file to disinfect oval-shaped root canals. J Endod 2010; 36:1860-5.

31. Vianna ME, Gomes BP. Efficacy of sodium hypochlorite combined with chlorhexidine against Enterococcus faecalis in vitro. Oral Surg Oral Med Oral Pathol Oral Radiol Endod 2009; 107:585-9.

32. Sassone LM, Fidel R, Fidel S, Vieira M, Hirata R Jr. The influence of organic load on the antimicrobial activity of different concentrations of $\mathrm{NaOCl}$ and chlorhexidine in vitro. Int Endod J 2003; 36:848-52.

33. Vianna ME, Gomes BP, Berber VB, Zaia AA, Ferraz $\mathrm{CC}$, de Souza-Filho FJ. In vitro evaluation of the antimicrobial activity of chlorhexidine and sodium hypochlorite. Oral Surg Oral Med Oral Pathol Oral Radiol Endod 2004;97:79-84

34. Manikandan R, Mithra N Hegde. Comparative evaluation of antimicrobial efficacy of routine endodontic irrigants with surfactants against MTAD on Enterococcus faecalis- An in vitro microbiological study. IJRRPAS 2012; 2(1):55-64.

35. Torabinejad M, Shabahang S, Aprecio RM, Kettering JD. The antimicrobial effect of MTAD: An In Vitro investigation. J Endod 2003; 29(6):400-403.

36. Davis JM, Maki J, Bahcall JK. An in vitro comparison of the antimicrobial effects of various endodontic medicaments on Enterococcus faecalis. J Endod 2007; 33:567-9.

37. Portenier I et al. Killing of E. faecalis by MTAD and Chlorhexidine digluconate with or without cetrimide in the presence or absence of dentin powder or BSA. $J$ Endod 2006;32(2):138-141

38. Jungbluth $\mathrm{H}$, Marending $\mathrm{M}$, DeoDeus $\mathrm{G}$ et al. Stabilizing sodium hypochlorite at high $\mathrm{pH}$ : Effects on soft tissue and dentin. J Endod 2011; 37(5):693-696.

39. Giardino L, Ambu E, Becce C, Rimondini L, Morra M. Surface tension comparison of four common root canal irrigants containing antibiotic. $J$ Endod 2006; 32(11):1091-1093.

40. Baca $\mathrm{P}$ et al. Residual effectiveness of final irrigation regimens on Enterococcus faecalis-infected canals. . $J$ Endod 2011; 37(8):1121-1123.

41. Baker NE etal. Antibacterial efficacy of calcium hydroxide, iodine potassium iodide, betadine, and betadine scrub with and without surfactant against E faecalis in vitro. Oral Surg Oral Med Oral Pathol Oral Radiol Endod 2004; 98:359-64.

42. Estrela $\mathrm{C}$ et al. A preliminary study of the antibacterial potential of cetylpyridinium chloride in root canals infected by E. faecalis. Braz Dent J 2012; 23(6):645653.

43. Oncag $\mathrm{O}$ et al. Comparison of antibacterial and toxic effects of various root canal irrigants. Int Endod $J$ $2003 ; 36: 423-432$. 
44. Piret J, Désormeaux A, Bergeron MG. Sodium lauryl sulfate, a microbicide effective against enveloped and nonenveloped viruses. Curr Drug Targets 2002; 3 (1): 17-30.

45. Piret $\mathrm{J}$ et al. In vitro and in vivo evaluations of sodium lauryl sulfate and dextran sulfate as microbicides against herpes simplex and human immunodeficiency viruses. J Clin Microbiol 2000; 38 (1): 110-9.
46. Rasimick BJ, Wan J, Musikant B, Deutsch AS. Stability of doxycycline and chlorhexidine adsorbed on root canal dentin. $J$ Endod 2010; 36(3):489-492.

47. Royal MJ, Williamson AE, Drake DR. Comparison of $5.25 \%$ sodium hypochlorite, MTAD, and $2 \%$ chlorhexidine in the rapid disinfection of polycaprolactone-based root canal filling material. $J$ Endod 2007; 33:42-4.

48. M. Balouiri et al. Methods for in vitro evaluating antimicrobial activity: A review. $J$ Pharmaceutical Analysis 2016;6: 71-79

\section{How to cite this article:}

Manikandan R et al (2017) 'Antimicrobial efficacy of endodontic irrigants and combination surfactant regimens on enterococcus faecalis. An in vitro microbiological study', International Journal of Current Advanced Research, 06(05), pp. 3740-3746. DOI: http://dx.doi.org/10.24327/ijcar.2017.3746.0360 